\title{
Commercial production of Oyster mushroom
}

\author{
Payal Mago 1., Isha Gunwal ${ }^{2}$., Lata Singh ${ }^{3}$., \& Deekshant Awasthi ${ }^{4}$ \\ ${ }^{I}$ (Depatment of Botany, Sri Aurobindo college, University of Delhi, New Delhi) \\ ${ }_{2}^{2}$ (Department of Botany, Sri Aurobindo college, University of Delhi, New Delhi) \\ ${ }^{3}$ (N.R.E.C College, Khurja, C.C.S University, Meerut) \\ ${ }^{4}$ (Department of Physics, Indian Institute Of Technology, New Delhi)
}

\begin{abstract}
Mushrooms have attracted the attention of man from very ancient times and the use of mushroom as food and drugs are closely related to the history of mankind and is as old as civilization itself. Best thing about edible and cultivable mushrooms is they can thrive well on several kinds of agricultural waste or by products such as wheat straw and rice straw, This work attempted to use leaf litter and saw dust mixed with traditional agricultural waste to cultivate two commercial varieties of oyster mushroom. The leaf liter either is collected and burnt creating environmental pollution or sometimes used in making compost. Saw dust also poses disposal problem due to its negligible secondary use. The use of leaf litter in mushroom production givers an alternative cellulose source for commercial production of mushrooms.
\end{abstract}

Keywords: Leaf litter, Mycelium, Oyster mushroom, Sporophores,

\section{Introduction}

Mushrooms have attracted the attention of man from very ancient times and the use of mushroom as food and drugs are closely related to the history of mankind and is as old as civilization itself. In nature they have been reported growing wild from snowy mountains to sandy deserts on all type of soils and ecosystems. They appear in all seasons, chiefly during rainy weather, wherever organic matter or its decomposition products are available. Three modes of living can be recognized among mushrooms- saprophytes, parasites or some facultative.

Lelley (12) described mushrooms as a weapon against starvation. Lately mushrooms are hailed as health food because apart from high and qualitatively good protein content (on dry wt. basis) mushrooms are good source of vitamin (B1, B2, C) minerals and have low fat contents. In developing and under developed countries large amounts of agricultural wastes are produced and their disposal pose environmental problem since they are resistant to degradation mainly due to presence of lignin. However, mushrooms are efficient fungi in metabolizing these residues.

In India three mushrooms are being cultivated namely viz. white button mushroom (Agaricus bisporus), paddy straw mushroom (Volvariella volacea), and the oyster mushroom (Pleurotus spp.). The most widely grown mushroom on a commercial scale is white button mushroom. Oyster .mushroom cultivation in picking up very fast in India. Subtropical and tropical climate of India is conducive for the growth of oyster mushroom as it thrives well in wide variation of temperature and moisture. Pleurotus $\mathrm{sp}$. has a tremendous organoleptic and nutritional appeal (10). Large varieties of biomass have been successfully utilized for cultivation of Pleurotus spp. But paddy straw is the most widely used substrate for commercial production of oyster mushroom.

The present work was initiated with the aim of demonstrating that some easily available sources (leaf litter and saw dust) could act as potential substrate for commercial production of oyster mushroom. Delbergia sissoo leaf litter was selected as it is a multipurpose tree and is widely available in the Delhi University campus. Sawdust is another commonly available waste from sawmill and furniture factories and poses disposal problems.

\section{Material And Method}

Two species of Pleurotus viz. P.sajor-caju and P. florida were cultivated on three different substratespaddy straw alone, paddy straw+ Dalbergia sisoo leaf litter, Paddy straw + sawdust.

\subsection{Experimental site-}

Experiment were conducted in a room of $5 \times 1 \mathrm{mt}$. with two iron trollies having wooden shelves $(1 \times 0.5$ $\mathrm{m}$ ) were kept. After clearing the room was fumigated using sulphur overnight. Experiments were initiated after 3 days. The door was covered with a sterilized black polythene to prevent contamination. 


\subsection{Substrates used-}

i) Paddy straw alone- $5 \mathrm{Kg}$ of straw was used as one of the substrate.

ii) Paddy straw + Dalbergia sisoo leaf litter- mixed in 1:1 ratio on dry wt. basis and $5 \mathrm{Kg}$ of this mixture was used.

iii) Paddy straw + sawdust- mixed in 1:1 ratio on dry wt. basis and $5 \mathrm{Kg}$ of this mixture was used.

\subsection{Spawn-}

Spawn of P. sajor-caju and P. florida prepared on wheat grains was obtained from commercial spawn supplier (Swadeshi farms, G.T. Karnal Road, Delhi).

\subsection{Substrate Preparation-}

All the 3 substrates were dried. They were pasteurized by hot water treatment. Boiling water was added to the substrates and substrates were allowed to remain in this water for 12 hours. After 12 hrs. of soaking period excess of water was drained off. The wet substrate had a moisture content of 75-78\%. The substrates were spread on a pre-sterilized polythene sheet and thoroughly spawned at $2 \%$ of the wet substrate.

\subsection{Cultivation in Polythene bags-}

Mushroom blocks/beds were prepared in $45 \mathrm{x} 55 \mathrm{~cm}$ sized polythene bags. Bags were filled with spawned substrate and closed to maintain high humidity during spawn run. 8-10 holes were made in the polybags arbitrarily for exchange of gases. No water was given during spawn run period. When mycelium completely covered the substrate in bags, making a compact mass polythene cover was removed from mycelia block of the substrate to provide sufficient aeration to encourage cropping. Room temperature varied from 25 to $30 * \mathrm{C}$. Variation in the relative humidity was $80-90 \%$. Humidity was maintained by wetting the walls and floor. Diffused light and fresh air was provided by opening the door for 2-3 hours every day. Blocks were kept moist by watering twice a day and watering was withheld a day before harvesting.

\subsection{Harvesting-}

The mature fruit bodies of Pleurotus spp. were picked when the edges of pelei started curl up. Fresh weight of mushrooms was recorded immediately after harvesting. Biological efficiency was calculated using the following relationship given by Chang et al. (6).

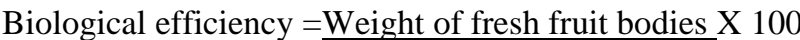 Dry weight of substrate}

The cultivation continued for 86 days and 3-4 flushes were harvested for P. sajor-caju and P. florida.

\section{Result And Discussion}

For the present studies three substrates were selected, namely paddy straw, mixture of paddy straw and leaf litter and paddy straw with sawdust "Plate 1 A-C". Complete impregnation of mycelium of P. sajor-caju was observed in thirteen days in paddy straw alone fifteen days in a mixture of paddy straw and leaf litter and seventeen days in substrate containing sawdust. Mycelium run was delayed in P. florida as compared to P.sajorcaju by three days in paddy straw and two days in mixture of paddy straw and leaf litter. While the spawn running period in paddy straw and sawdust was same for both the species studied "Table 3". Primordial formation was obtained earlier on paddy straw as compared to other two substrates in P. sajor-caju while in P.florida, the pinning was first observed on paddy straw and sawdust. Within few days mushrooms sprouted from all over the surface of substrates and all the subsequent stages of growth were observed "Plates $2 \mathbf{2} \mathbf{3} \mathbf{A}$ D". Three harvests of P. sajor-caju were made on paddy straw and sawdust as against four on other two substrates. P. florida produced three crops on all three substrates till termination of the experiment "Table 1 and 2". In P. florida first harvest was made after 37-42 days of cropping period by which time a second harvest could be obtained for P. sajor-caju and by the end of second flush of P. florida all four flushes of P. sajor-caju were harvested. Total cropping period of P. sajor-caju was 72-73 days and 83-86 days for P. florida“Table 3". Maximum number of sporophores and yield were obtained during the first flush, while there was a decline during the sudsequent flushes "Table 1 and 2". The highest yield as well as number of sporophores of P. sajorcaju and P.florida was achieved in the control i.e. paddy straw followed by paddy straw + leaf litter and paddy straw + sawdust (Plates 8 \& 9A-C). Biological efficiency of P. sajor-caju was recorded to be $82.84 \%$ on paddy straw, $61.06 \%$ on leaf litter and $55.26 \%$ on sawdust containing substrate P. florida gave bioefficiency of $75.7 \%$, $73.56 \%$ and $51.42 \%$ on paddy straw, leaf litter and sawdust containing substrates respectively "Table 3".

In the present study, the cultivation of two oyster mushrooms namely P. sajor-caju and P. florida was carried out. For this three substrates were taken into account. The total cultivation period was 86 days with 3-4 consecutive harvestings. Mycelial spreading of the oyster mushroom was best on paddy straw than the other two 
substrares. The colonization depends mainly on the availability of nutrients and physical structures of substrates. Sawdust and leaf litter being less readily decomposable showed slight delay in mycelia impregnation as compared to paddy straw. The variation in spawn run period on different substrates has been reported earlier $(5,7,9)$. The maximum yield was obtained during the first flush which declined during the subsequent flushes. Similar trend has been observed by earlier workers, however, Chang et al. (6) observed a uniform distribution of fruit bodies in all flushes of P.sajor-caju on cotton waste.

National Academy of Sciences (14) has proposed that the average yield of fresh mushrooms is $1 \mathrm{~kg} / \mathrm{kg}$ of dry straw used. In the present study, the paddy straw $(1 \mathrm{~kg})$ has showed a maximum yield of $828 \mathrm{gm}$ and 927 gms for P. sajor-caju and P.florida respectively. Similarly, variations have been reported earlier (3, 6, 8, 13, 20). Variations in the yield may be attributed in part of different Pleurotus spp., difference in growing conditions and pre-treatment methods of paddy straw.When the paddy straw was mixed with other substrates (1:1, dry wt. basis) namely, leaf litter and sawdust, lower yield of oyster mushroom was obtained. This could be due to improper substrate treatment, lack of ambient temperature and other cultural conditions. The bioefficiency of Pleurotus was maximum on paddy straw alone as compared to mixed substrates. Low yield of different Pleurotus spp. has been observed when cultivated on paddy straw mixed with Eleocharis plantogena, Chromolaena, banana leaves, sugarcane trash as compared to paddy straw alone $(1,15,17,19)$. However, when paddy straw was mixed with Sesbania grandiflora, better yield was obtained as compared to paddy straw alone (4).

In the present study, fruiting was observed earlier in P. sajor-caju as compared to P. florida as all the substrates used. P. florida gave better yield than P. sajor-caju paddy straw alone and also, when mixed with leaf litter, while the yield of P. sajor-caju was more on paddy straw + sawdust. Working on similar lines, Khan et al. (1981) also reported better yield of P. florida as compared to P. sajor-caju on paddy straw along with earlier fruiting in the former species.The earlier reports of Savalgi and Savalgi (16) and Singh et al. (17) showed better yield of P. florida as compared to P.sajor-caju. In comparison to these, contrary results were given by Bahukandi and Munjal (2); Shivaprakasam and Ramaraj (18

\section{Tables And Plates}

Table1. Yield potential of Pleurotus sajor-caju and Pleurotus florida on different substrates

\begin{tabular}{|c|c|c|c|c|c|c|}
\hline \multirow[t]{2}{*}{ Pleurotus spp. } & \multirow[t]{2}{*}{ Substrates } & \multicolumn{4}{|c|}{$\begin{array}{l}\text { Yield (in gms) of fresh mushrooms } / 5 \mathrm{~kg} \\
\text { dry substrate }\end{array}$} & \multirow[t]{2}{*}{ Total Yield (in gms) } \\
\hline & & Flush & $\begin{array}{l}2^{\text {nd }} \\
\text { Flush }\end{array}$ & $\begin{array}{l}3^{\text {rd }} \\
\text { Flush }\end{array}$ & $\begin{array}{l}4^{\text {th }} \\
\text { Flush }\end{array}$ & \\
\hline \multicolumn{7}{|l|}{ P. sajor-caju } \\
\hline & Paddy straw & 2262 & 1009 & 521 & 352 & 4142 \\
\hline & $\begin{array}{l}\text { Paddy straw + leaf litter } \\
(1: 1)\end{array}$ & 1464 & 844 & 375 & 370 & 3053 \\
\hline & $\begin{array}{l}\text { Paddy straw + sawdust } \\
(1: 1)\end{array}$ & 1816 & 727 & 220 & - & 2763 \\
\hline \multicolumn{7}{|l|}{ P. florida } \\
\hline & Paddy straw & 3986 & 419 & 380 & - & 4785 \\
\hline & $\begin{array}{l}\text { Paddy straw + leaf litter } \\
(1: 1)\end{array}$ & 3078 & 350 & 250 & - & 3678 \\
\hline & $\begin{array}{l}\text { Paddy straw + sawdust } \\
(1: 1)\end{array}$ & 1696 & 495 & 380 & - & 251 \\
\hline
\end{tabular}

Table 2. Effect of different substrates on number of sporophores produced.

\begin{tabular}{|c|c|c|c|c|c|c|}
\hline \multirow[t]{2}{*}{ Pleurotus spp. } & \multirow[t]{2}{*}{ Substrates } & \multicolumn{4}{|c|}{$\begin{array}{l}\text { No. of sporophores produced } / 5 \mathrm{~kg} \text { of dry } \\
\text { substrate }\end{array}$} & \multirow{2}{*}{$\begin{array}{l}\text { Total no. of } \\
\text { sporophores } \\
\text { produced }\end{array}$} \\
\hline & & $\begin{array}{l}1^{\text {st }} \\
\text { Flush }\end{array}$ & \begin{tabular}{l|l}
$\mathbf{2}^{\text {nd }}$ \\
Flush
\end{tabular} & \begin{tabular}{|l|l|} 
Flush \\
\end{tabular} & $\begin{array}{l}4^{\text {th }} \\
\text { Flush }\end{array}$ & \\
\hline \multicolumn{7}{|l|}{ P. sajor-caju } \\
\hline & Paddy straw & 287 & 145 & 53 & 180 & 665 \\
\hline & $\begin{array}{l}\text { Paddy straw + leaf litter } \\
(1: 1)\end{array}$ & 256 & 185 & 74 & 127 & 642 \\
\hline & $\begin{array}{l}\text { Paddy straw }+ \text { sawdust } \\
(1: 1)\end{array}$ & 278 & 120 & 50 & - & 448 \\
\hline \multicolumn{7}{|l|}{ P. florida } \\
\hline & Paddy straw & 444 & 71 & 99 & - & 614 \\
\hline & $\begin{array}{l}\text { Paddy straw + leaf litter } \\
(1: 1)\end{array}$ & 389 & 31 & 15 & - & 435 \\
\hline & $\begin{array}{l}\text { Paddy straw }+ \text { sawdust } \\
(1: 1)\end{array}$ & 200 & 54 & 115 & - & 369 \\
\hline
\end{tabular}


Table 3. Study on productivity of P. sajor-caju and P. florida and their biological efficiency

\begin{tabular}{|c|c|c|c|c|c|c|c|}
\hline $\begin{array}{l}\text { Pleurotus } \\
\text { spp }\end{array}$ & Substrates & $\begin{array}{l}\text { Spawn } \\
\text { period } \\
\text { (in days) }\end{array}$ & $\begin{array}{l}\text { Total } \\
\text { cropping } \\
\text { period (in } \\
\text { days) with } \\
\text { av. Of 3-4 } \\
\text { flushes }\end{array}$ & $\begin{array}{l}\text { Total no. } \\
\text { of } \\
\text { sporophor } \\
\text { es } \\
\text { produced/ } \\
5 \mathrm{~kg} \text { of dry } \\
\text { substrate }\end{array}$ & $\begin{array}{l}\text { Total } \\
\text { yield/5 } \mathbf{k g} \\
\text { of dry } \\
\text { substrate }\end{array}$ & $\begin{array}{l}\text { Biological } \\
\text { efficiency } \\
(\%)\end{array}$ & $\begin{array}{l}\text { \% increase } \\
(+) \text { or } \\
\text { decrease }(- \\
) \text { over } \\
\text { control }\end{array}$ \\
\hline \multicolumn{8}{|l|}{ P. sajor-caju } \\
\hline & Paddy straw & 13 & 72 & 665 & 4142 & 82.84 & \\
\hline & $\begin{array}{ll}\text { Paddy } & \text { straw } \\
+\quad \text { leaf } & \text { litter } \\
(1: 1) & \end{array}$ & 15 & 72 & 642 & 3053 & 61.06 & -21.78 \\
\hline & $\begin{array}{l}\text { Paddy straw } \\
+\quad \text { sawdust } \\
(1: 1)\end{array}$ & 17 & 73 & 448 & 2763 & 55.26 & -27.58 \\
\hline \multicolumn{8}{|l|}{ P. florida } \\
\hline & Paddy straw & 16 & 86 & 614 & 4785 & 95.7 & \\
\hline & $\begin{array}{ll}\text { Paddy } & \text { straw } \\
+\quad \text { leaf } & \text { litter } \\
(1: 1) & \end{array}$ & 17 & 83 & 435 & 3678 & 73.56 & -22.14 \\
\hline & $\begin{array}{lr}\text { Paddy } & \text { straw } \\
+\quad & \text { sawdust } \\
(1: 1) & \end{array}$ & 17 & 86 & 369 & 2571 & 51.42 & -44.28 \\
\hline
\end{tabular}
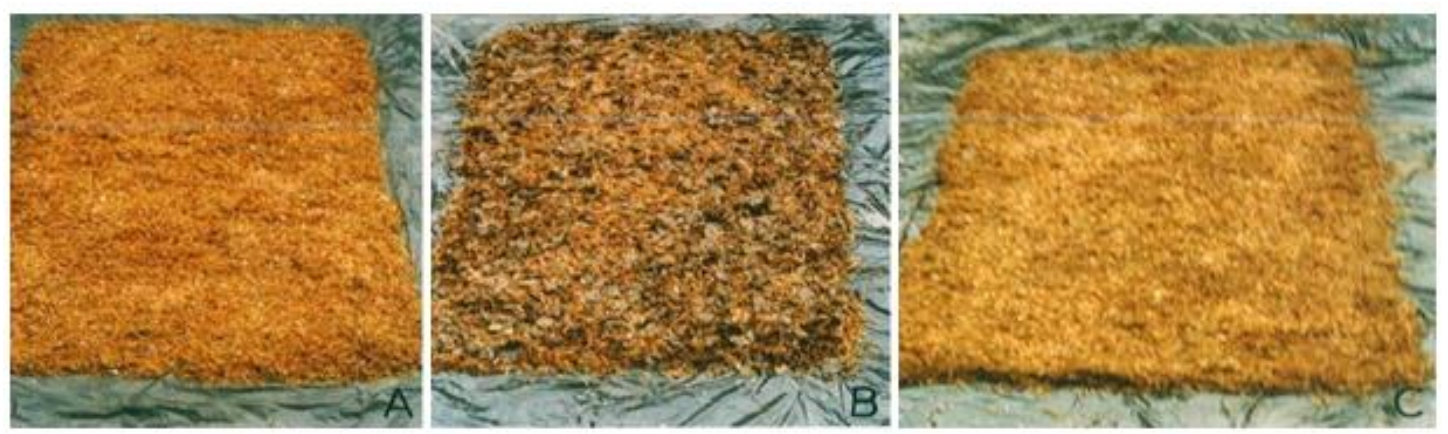

Plate 1: Beds of different substrates mixed with spawn- (A) Paddy straw, (B) Paddy straw + leaf litter, (C) Paddy straw + sawdust
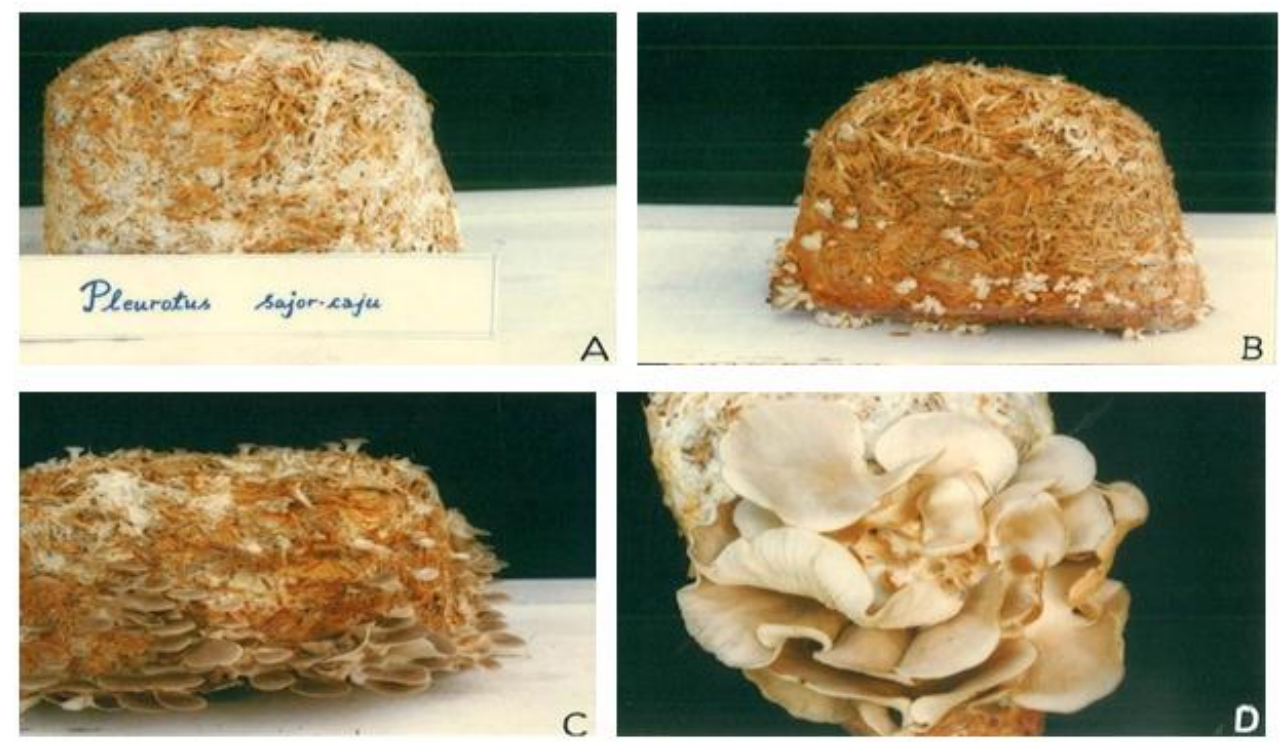

Plate 2: (A-D) Different stages of growth in P. sajor-caju 

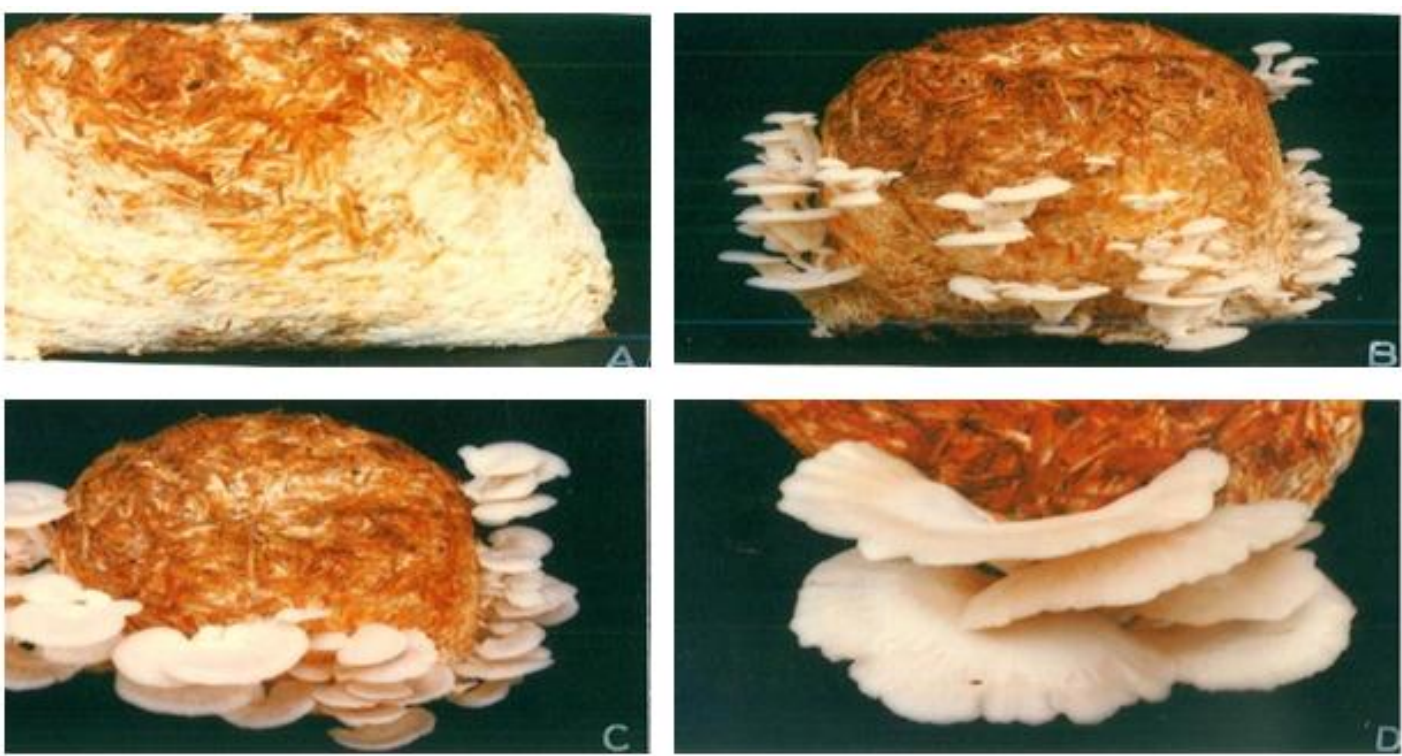

Plate 3: (A-D) Different stages of growth in P. Florida

\section{Conclusion}

Paddy straw is the most suitable substrate for commercial production of oyster mushroom. Different substrates used in combination with paddy straw in the present studies have also shown encouraging results. Present work was a preliminary investigation and yield on these substrates can be increased by suitably modifying the substrate treatment. P. florida yielded more with the same investment and gave higher profit. Hence, it is more suitable for commercial production. Mushroom cultivation can be a potential source of sizable income for rural people, unemployed youth, housewives and many public organization as it requires minimum material input and space.

\section{Acknowledement}

The authors are thankful to the Department of Botany, University of Rajasthan and University of Delhi for providing necessary laboratory facilities. We gratefully acknowledge the Department of Environmental studies, University of Delhi, New Delhi, for helping us to analyze the samples for heavy metals. We are thankful to Sri Aurobindo College for moral support and encouragement.

\section{Refrences}

[1]. Abraham, T.K. and Pradeep, N.S. Utilization of a common weed- Chromolaena odorata (L.) King \& Robinson, as a substrate for oyster mushroom cultivation. Mush. Res. 4, 1995. 81-84.

[2]. Bahukhandi, D. and Munjal, R.L. Cultivation of Pleurotus species on different agricultural residues. Indian phytopath. 42 (4), 1989. 492-495.

[3]. Bisaria, B.; Madan, M. and Bisaria, V.S. Biological efficiency and nutritive value of Pleurotus sajor-caju cultivated on different agro-wastes. Biological Wastes, 19, 1987. 239-255.

[4]. Chanda, S.; Chakrabarti, S.; Das, S. and Dey, R.K. Cultivation of Pleurotus sajor-caju on leaf fibre residues of Sesbania grandiflora. In: Mush. Res. 2, 1993. 96.

[5]. Chander, R.S. Evaluation of substrates and supplements for the oyster mushroom (Pleurotus florida) cultivation in the state of Goa. In: Indian Mushrooms. Proc. Nat. Symp. Mush. (ED. M. C. Nair). Kerala Agricultural Univ., Trivandrum, pp. 93-96. 1991.

[6]. Chang, S.T.; Lan, O.W. and Cho, K.Y. The cultivation and nutritional value of Pleurotus sajor-caju. Eur. J. Appl. Microbiol. Biotechnol. 12, 1981.58-62.

[7]. Daniel, T.; Kumuthakalavalli, R. and Shanmugam, S. Study of oyster mushroom (Pleurotus sajor-caju) cultivation on various substrates. In: Indian Mushrooms. Proc. Nat. Symp. Mush. (ed. M.C. Nair). Kerala Agricultural Univ., Trivandrum. Pp.86-88, 1991.

[8]. Dhanda, S.; Garcha, H.S.; Kakkar, V.K. and Makkar, G.S. Improvement in feed value of paddy straw by Pleurotus cultivation. Mush. Res. 5, 1996. 1-4.

[9]. Eyini, M.; Prema, P. and Jayakumar, M. Cultivation trails of Pleurotus ostreatus Kummer, on lime water pretreated coir waste and paddy waste. Mush. Res. 4, 1995. 77-80.

[10]. Garcha, H.S; Khanna, P.K.. and Dhanda, S. Pleurotus cultivation- forest scenario and production. In: Indian Mushroom Conference, Sept. 10-12, Solan. P.84, 1997. (Abstract).

[11]. Khan, S.M.; Kausar, A.G. and Ali, M.A. Yield performance of different strains of oyster mushrooms (Pleurotus spp.) on paddy dtraw in Pakistan. Mush. Sci. 11(2), 1981.675-678.

[12]. Lalley, J. Edible mushrooms as a weapon against starvation. Mush. J. Tropics. 7, 1987.135-140.

[13]. Mahmoud, B.H. and Elkattan, M.H. Edible oyster mushroom cultivation on rice straw. Mush. J. Tropics. 9, 1989. 37-42.

[14]. National Academy of Sciences . Food from wastes. In: Food, fuel and fertilizer from organic wastes. Report of the National Academy of Sciences, National Academy Press, Washington D.C., 27-42. 1981.

[15]. Patra, A.K. and Pani, B.K. Evaluation of banana leaf straw as a new alternate substrate to paddy straw for oyster mushroom cultivation. J. Phytol. Res. 8(2), 1995. 145-148. 
[16]. Savalgi, V. and Savalgi, V.P. Studies on cultivation of oyster mushrooms on different farm waste substrates in Karnataka. In: Indian mushrooms. Proc. Nat. Symp. Mush. Kerala Agricultural University, Trivandrum. pp. 108-112. 1991.

[17]. Singh, S.; Rana, R.S. and Srivastava, M.P. Studies on yield of different oyster mushroom species in Haryana conditions. In: Indian Mushroom Conference, Sept. 10-12, Solan. pp. 7, 1997. (Abstract)

[18]. Sivaprakasam, K. and Ramaraj, R. Studies on some factors influencing the yield of oyster mushroom. In: Indian Mushrooms . Proc. Nat. Symp. Mush. (ed. M.C. Nair) Kerala Agricultural Univ.,Trivandrum. pp. 127-132. 1991.

[19]. Suharban, M.; Mathew, A.V. and Mathai, G. Eliocharis plantogena R. Br. a common weed - an alternate substrate for oyster mushroom. Mush. Res. 2. 1993. 97.

[20]. Vats, S.K..; Sood, R.P.; Gulati, S. and Sharma, O. P.. Lantana camara L. - Alignocellulonic substrate for cultivation of Pleurotus sajor-caju. Biores. Technol. 48. 1994, 49-52. 